\title{
Three new additions to the grass flora of Sikkim
}

\author{
C.S. Purohit四 \\ Botanical Survey of India, Arid Zone Regional Centre, Pal Basni link road, Subhash Nagar, AllMS road, Jodhpur, \\ Rajasthan - 342014, India \\ 凶Corresponding Author: chandansinghpurohit@yahoo.com

\section{सिक्किम की घास वनस्पतियों कें तीन नये संयोजन}

\section{सारांश}

प्रस्तुत शोध पत्र 3 घास जातियों की प्राप्ति पर आधारित है, जिनमें ऐरेक्ने रेसिमोसा (हासनी एक्स रोइम एवं शुल्ट.) ओट्टवाई, डिजिटेरिया वाईकोर्निस (लैम.) रोइम. एवं शुल्ट. एक्स लाउड एवं पोआ सुपिना शार्ड. सम्मिलित हैं। उपरोक्त तीनों जातियाँ सिक्किम राज्य के लिये नये अभिलेख के रूप में दर्ज की गई हैं, जिनका सही उद्धरण, वर्णन एवं फलोद्रिकी को शोध पत्र में दिया गया है।

\section{ABSTRACT}

The present communication deals with the occurrence of 3 grass species viz. Acrachne racemosa (Heyne ex Roem. \& Schult.) Ohwi, Digitaria bicornis (Lam.) Roem. \& Schult. ex Loud., and Poa supina Schard. as a new records for Sikkim along with their correct citation, description and phenology.

Keywords: Addition, Flora, Poaceae, Sikkim.

\section{INTRODUCTION}

Sikkim with about 7,299 sq.km of geographic area is the smallest state in North east India. The state shares its border on the south with Darjeeling district of west Bengal, on the north and north- east with China (Tibet), on the east by Bhutan and while on the west by Nepal. This state being a part of eastern Himalayas having varied elevation ranging from 300 to $8540 \mathrm{~m}$ and the varied type of forest from tropical to alpine (Singh \& Chauhan, 1997; 2000). During the routine exploration tours in the North district of the state, the author collected three interesting species of Grasses. On scrutiny of literature (Hooker, 1897; Bor, 1960; Cope, 1982; Moulik, 1997; Bennet, 1983; Krishna \& Singh, 1987; Kartikeyan \& al., 1989; Noltie, 2000; Singh $\&$ Sanjappa, 2011) these three species were identified as Acrachne racemosa (Heyne ex Roem. \& Schult.) Ohwi, Digitaria bicornis (Lam.) Roem. \& Schult. ex Loud. and Poa supina Schard. hitherto unknown from Sikkim. All the species are reported herewith with the correct citation, brief description, an illustration, phonology and details of specimens examined. All the specimens have been deposited in the, Botanical Survey of India, Sikkim Himalayan Regional Centre (BSHC), Sikkim. 

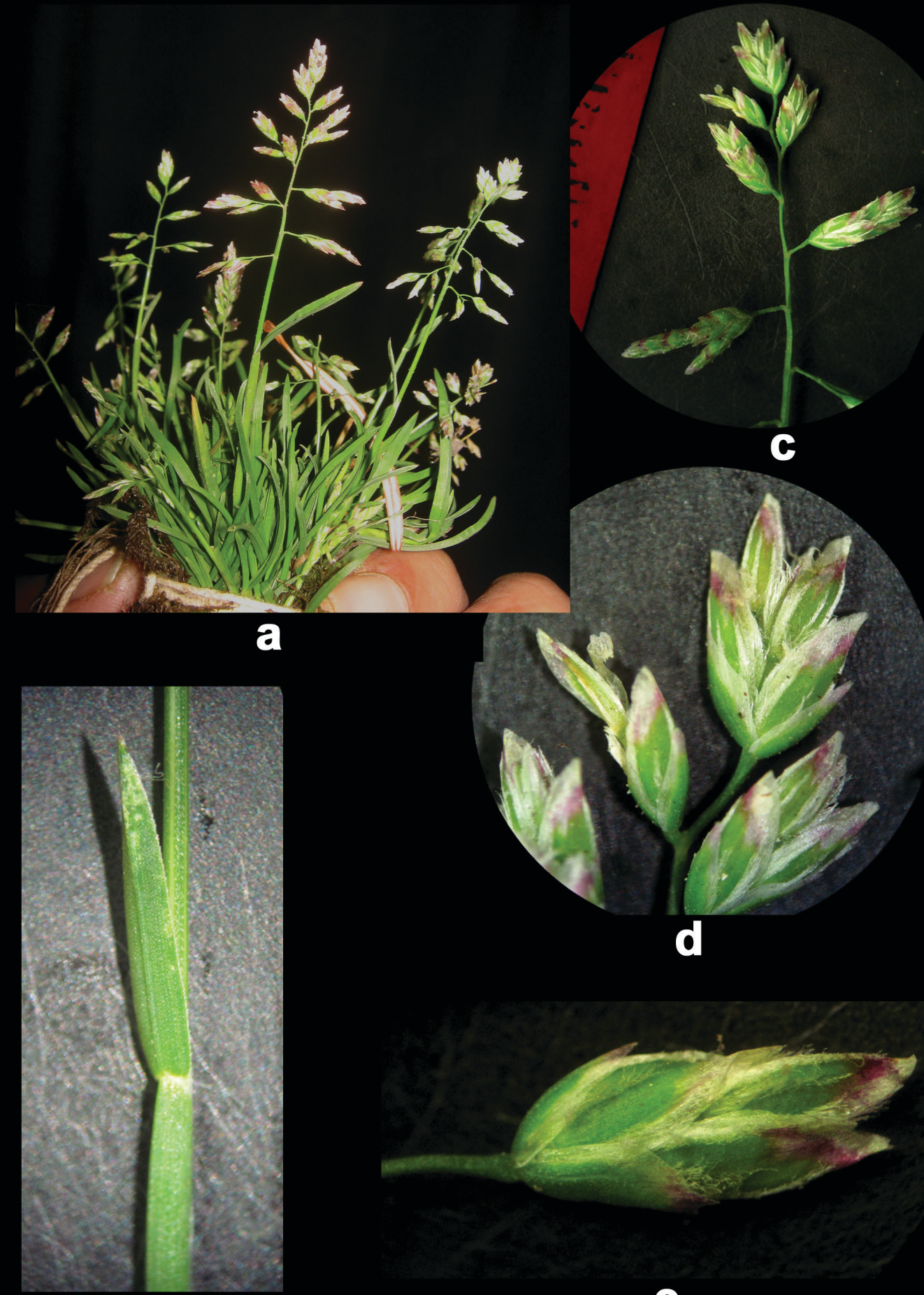

b

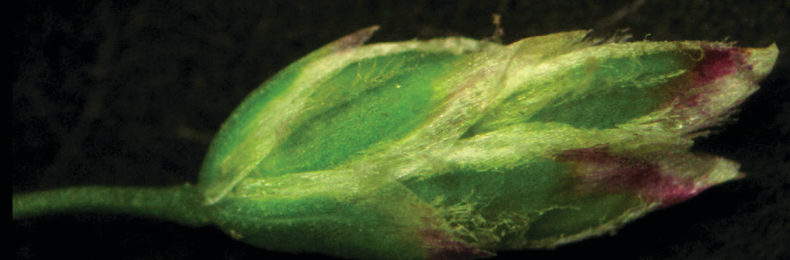

$\theta$

Plate -1: Poa supina Schrad. (Poaceae)- a. Whole plant; b. Leaf; c. Inflorescence; d. Arrangement of spikelets; e. Close-up of spikelet. 


\section{ENUMERATION OF SPECIES}

Acrachne racemosa (Heyne ex Roem. \& Schult.) Ohwi in Bull. Tokyo Sci. Mus. No. 18: 1, 1947. Eleusine racemosa B. Heyne ex Roth Syst. Veg., ed. 15 bis [Roemer \& Schultes] 2: 583. 1817.

Annuals. Culms geniculately ascending or decumbent; Inflorescence- composed of racemes; spikes usually in pseudo-whorls or scattered; spikelet 8-20 flowered; grain coarsely rugose, grooved or hollowed on one face, with an early deciduous pericarp.

Flowering and Flowering: July-September;

Specimen examined- Sikkim: North district, Mangthan, 24.04.2013, CS Purohit 37225 (BSHC).

Digitaria bicornis (Lam.) Roem. \& Schult. Syst. Veg., ed. 15 bis [Roemer \& Schultes] 2: 470. 1817. Paspalum bicorne Lam. Tabl. Encycl. 1: 176. 1791.

Annuals. Culms decumbent, $20-45 \mathrm{~cm}$ long; Ligule an eciliate membrane, $2 \mathrm{~cm}$ long; Inflorescence composed of racemes; racemes stout, very stiff, 2 , divericate; sessile spikelets nearly glabrous in front, pedicellate spikelet with long hairs often spreading at maturity. Lower lemma of sessile spikelet with prominent nerves, the inter-nerve spaces often slit-like.

Flowering and Fruiting: August-October;

Specimen examined- Sikkim: North district, Chungthang, 21.08.2012, C S Purohit 37184 (BSHC-47441);

Poa supina Schard. Fl. Germ. 1: 289, 1806.

Perennials. Culm decumbent, $6-25 \mathrm{~cm}$ long. Panicle open, 2-3 cm long, spikelets clustered towards branch tips. Fertile spikelets breaking up at maturity. Intermediate nerves of lemma glabrous. Anthers $1.2-1.6 \mathrm{~mm}$ long.

Flowering and Fruiting: Almost throughout the year.

Specimen examined- Sikkim: North district, Shingba Rhododendron Wild Life Sanctuary, 02.05.2014, CS Purohit 38194 (BSHC-47437);

\section{ACKNOWLEDGEMENTS}

The author is thankful to Dr. Paramjit Singh, Director, Botanical Survey of India, Kolkata for facilities and
Scientist In-charge, BSI-SHRC, Sikkim for providing all facilities during the study. Thanks is also extended to State forest Department, Sikkim for permitting to survey in the protected areas.

\section{REFERENCES}

BENNET, S.S.R., 1983. Ethnobotanical studies in Sikkim. Ind. For. 109: 477-481;

BOR N.L. 1960. The Grasses of Burma, Ceylon, India and Pakistan, Vol. 1, London.

Cope T.A. 1982. Flora of Pakistan, vol. 143. In: E. Nasir and S.A. Ali (Eds.) Flora of Pakistan. Pakistan Agricultural Research Council and University of Karachi, Pakistan.

HOOKER, J.D. 1897. Flora of British India. Vol. VII. London. Page 842. (Reprinted in 1982 by Bishen Singh Mahendra Pal Singh, Dehra Dun, Vol. VII.)

KARTHIKEYAN, S., S.K. JAIN, M.P. NAYAR, AND M. SANJAPPA 1989. Florae Indicae Enumeratio Monocotyledonae. Botanical Survey of India, Calcutta.

KRISHNA B. AND S. SINGH 1987. Ethnobotanical observations in Sikkim. J. Econ. Taxon. Bot., 9(1): 1-7.

MOULIK S. 1997. The Grasses and Bamboos of India Vol. I-II. Scientific Publishers, Jodhpur.

NOLTIE H.J. 2000. Flora of Bhutan including a record of plants from Sikkim Vol. 3 part 2- The Grasses of Bhutan. Royal Botanic Garden, Edinburgh.

SINGH P. AND A.S. CHAUHAN 1997. Plant Diversity in Sikkim Himalaya. in: Hajra PK and V Mudgal (ed.), Plant diversity Hotspots of India, An Overview. pp. 137-158. Botanical Survey of India, Kolkata.

SINGH P. AND A.S. CHAUHAN 2000. Sikkim: in Floristic diversity and conservation strategies in India. Botanical Survey of India. Howrah. pp. 1419-1446.

SINGH P. AND M. SANJAPPA 2011. Flowering plants of Sikkim-an Analysis (in Biodiversity of Sikkim Exploring and Conserving a Global Hot Spots Eds.: ML Arrawatia and Sandeep Tambe), Govt. Sikkim Publication. 65-88. 